\title{
The effect of transcutaneous electric nerve stimulation on chronic postoperative pain and long-term quality of life
}

\author{
Transkütanöz elektrikli sinir uyarımının kronik ameliyat sonrası \\ kronik ağrı ve uzun dönem yaşam kalitesine etkisi
}

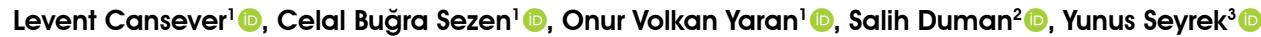

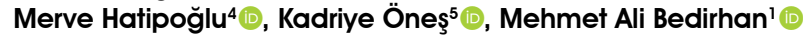

Institution where the research was done:

University of Health Sciences, Yedikule Chest Diseases and Thoracic Surgery Training and Research Hospital, Istanbul, Turkey

\section{Author Affiliations:}

'Department of Thoracic Surgery, University of Health Sciences, Yedikule Chest Diseases and Thoracic Surgery Training and Research Hospital, Istanbul, Turkey

${ }^{2}$ Department of Thoracic Surgery, Istanbul University Istanbul Medical School, Istanbul, Turkey

${ }^{3}$ Department of Thoracic Surgery, University of Health Sciences, Mehmet Akif Ersoy Thoracic and Cardiovascular Surgery Training and Research Hospital, Istanbul, Turkey

${ }^{4}$ Department of Thoracic Surgery, Ankara City Hospital, Ankara, Turkey

${ }^{5}$ Department of Thoracic Surgery, University of Health Sciences, Istanbul Physical Therapy Rehabilitation Training and Research Hospital, Istanbul, Turkey

\section{ABSTRACT}

Background: This study aims to investigate the effects of transcutaneous electrical nerve stimulation on early-stage postoperative pain and long-term quality of life in patients undergoing thoracotomy.

Methods: Between January 2019 and September 2019, a total of 100 patients (76 males, 24 females; mean age: $57.9 \pm 11.9$ years; range, 51 to 79 years) who underwent thoracotomy due to benign or malignant lesions were included The patients were divided into two groups: 50 patients who received transcutaneous electrical nerve stimulation (Group 1) and a control group of 50 patients who did not receive transcutaneous electrical nerve stimulation (Group 2). The Short Form-36 life quality scale was used to evaluate patients' quality of life at one month before and after surgery.

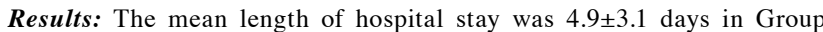
1 and $6.2 \pm 4.6$ days in Group $2(\mathrm{p}=0.008)$. There were no statistically significant differences in early-stage postoperative pain scores between the groups $(\mathrm{p}>0.05)$. Compared to Group 2, Group 1 had significantly lower pain scores and higher life quality scores pre- and postoperatively $(\mathrm{p}<0.05)$.

Conclusion: Transcutaneous electrical nerve stimulation is an effective method to manage chronic pain in the postoperative period. On the other hand, it does not effectively reduce early-stage postoperative pain or affect complication rates. The prevention of chronic postoperative pain by transcutaneous electrical nerve stimulation improves long-term quality of life of patients.

Keywords: Postoperative pain, quality of life, surgery, thoracic surgery, transcutaneous electrical nerve stimulation.
$\ddot{O} Z$

Amaç: Bu çalışmada torakotomi yapılan hastalarda transkütanöz elektrikli sinir uyarımının erken dönem ameliyat sonrası ağrı ve uzun dönem yaşam kalitesi üzerine etkileri incelendi.

Çalışma planı: Ocak 2019 - Eylül 2019 tarihleri arasında benign veya malign lezyonlar nedeniyle torakotomi yapılan toplam 100 hasta (76 erkek, 24 kadın; ort. yaş: $57.9 \pm 11.9$ yıl; dağılım, 51-79 yıl) çalışmaya dahil edildi. Hastalar iki gruba ayrıldı: 50 hastaya transkütanöz elektrikli sinir uyarımı uygulandı (Grup 1) ve 50 hastadan oluşan kontrol grubuna (Grup 2) transkütanöz elektrikli sinir uyarımı uygulanmadı. Ameliyat öncesi ve ameliyat sonrası birinci aylarda hastaların yaşam kalitesini değerlendirmek için Kısa Form-36 yaşam kalitesi ölçeği kullanıldı.

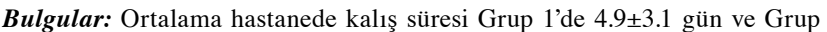
2 'de $6.2 \pm 4.6$ gün idi $(\mathrm{p}=0.008)$. İki grup arasında erken dönem ameliyat sonrası ağrı skorları açısından istatistiksel olarak anlamlı bir fark yoktu ( $p>0.05)$. Ameliyat öncesi ve sonrasında Grup 2'ye kıyasla, Grup 1'in ağrı skorları anlamlı düzeyde daha düşük ve yaşam kalitesi skorları daha yüksek idi $(\mathrm{p}<0.05)$.

Sonuç: Transkütanöz elektrikli sinir uyarımı ameliyat sonrası dönemde kronik ağrıyı yönetmede etkili bir yöntemdir. Ancak, erken dönem ameliyat ağrısını etkili düzeyde azaltmaz veya komplikasyon oranlarını etkilemez. Transkütanöz elektrikli sinir uyarımı ile ameliyat sonrası kronik ağrının engellenmesi, hastaların uzun dönemde yaşam kalitesini artırmaktadır.

Anahtar sözcükler: Ameliyat sonrası ağrı, yaşam kalitesi, cerrahi, göğüs cerrahi, transkütanöz elektrikli sinir uyarımı.

Received: April 06, 2020 Accepted: June 10, 2020 Published online: October 20, 2021

Correspondence: Levent Cansever, MD. SBÜ Yedikule Göğüs Hastalıkları ve Göğüs Cerrahisi Eğitim ve Araştırma Hastanesi Göğüs Cerrahisi Kliniği, 34020 Zeytinburnu, İstanbul, Türkiye. Tel: +90 532 - 2270888 e-mail: Icansever@yahoo.com 
Despite advanced invasive surgical techniques and anesthetic equipment, the pain remains one of the most important complications in the postoperative period following thoracotomy. ${ }^{[1]}$ Postoperative pain increases hospitalization time and decreases the quality of life and, thus, is a significant source of concern for thoracic surgery patients. ${ }^{[2]}$ Intercostal nerve traction is thought to be the most important factor in pain development. ${ }^{[1-4]}$ To mitigate pain, several surgical techniques such as intercostal sutures, double-edge closure, video thoracoscopic approaches, and neural block techniques are performed. ${ }^{[5-8]}$ Transcutaneous electrical nerve stimulation (TENS) is an effective non-invasive method for reducing pain, particularly in the early postoperative period $;^{[9,10]}$ however, there are scarce data regarding the patients' long-term quality of life and chronic pain.

In the present study, we aimed to investigate the effects of TENS on early and chronic postoperative neuropathic pain and long-term quality of life in thoracotomy patients.

\section{PATIENTS AND METHODS}

This single-centered, prospective study was conducted at Yedikule Chest Disease and Thoracic Surgery Training and Research Center, Department of Thoracic Surgery between January 2019 and September 2019. A total of 100 patients (76 males, 24 females; mean age: $57.9 \pm 11.9$ years; range, 51 to 79 years) who underwent thoracotomy due to benign or malignant lesions were included. The patients were divided into two groups: 50 patients who received TENS (Group 1) and a control group (Group 2) of 50 patients who did not receive TENS. Cancer patients who received neoadjuvant therapy (i.e., chemotherapy, chemoradiotherapy or radiotherapy), patients with chest wall invasion, those with a history of rib fracture, and those who had multiple rib fractures intraoperatively were excluded from the study. Comorbidity scores were calculated according to the modified Charlson Comorbidity Index (CCI). ${ }^{[11]}$ A written informed consent was obtained from each patient. The study protocol was approved by the Istanbul Training and Research Hospital Institutional Review Board (9/11/2018-1487). The study was conducted in accordance with the principles of the Declaration of Helsinki.

\section{Surgical technique}

Thoracotomy was performed in all patients included in the study. Thoracotomy was performed in wedge resections, when thoracoscopy was unfavorable. No epidural catheter was inserted preoperatively.

Following double-lumen selective intubation, the patients were placed in the lateral decubitus position for surgery. A 12 to $20-\mathrm{cm}$ posterolateral thoracotomy incision was made. The chest wall was entered through the fifth intercostal space, while preserving the musculus serratus anterior. After completing the pulmonary resection, the intercostal space was closed with two polyglactin sutures. Surgery was completed after inserting a 32-Fr thoracic drainage tube via the eighth or ninth intercostal space.

The patients who underwent postoperative TENS were treated with high-frequency stimulation using the Braun TENS device (B. Braun Taiwan Co., Ltd. New Tapei City, Songshan District, Taiwan). The TENS setting was calibrated as a biphasic waveform at $100 \mathrm{pulse} / \mathrm{s}$, and a pulse width of 200 Ms. Four sterile $5 \times 5 \mathrm{~cm}$ electrodes were placed 2 to $4 \mathrm{~cm}$ distant and parallel to the thoracotomy incision. The patients received TENS postoperatively with 8-h intervals. Both groups had intramuscular diclofenac sodium $75 \mathrm{mg}$ twice a day and intravenous tramadol hydrochloride $100 \mathrm{mg}$ three times per day. Paracetamol was used for additional pain control, as needed.

\section{Postoperative follow-up}

Patients' pain levels were evaluated routinely in every $6 \mathrm{~h}$ starting on the first postoperative day. The Visual Analog Scale (VAS) was used to evaluate pain scores, where 0 indicates no pain and 10 indicates the worst pain of the patient. ${ }^{[12]}$ Patients' pain scores were calculated for postoperative three consecutive days.

The pain scoring scale modulated by Jensen et al. ${ }^{[13]}$ was used at the end of the first postoperative week. While evaluating the pain score, 0 indicates no pain, 10 indicates the worst pain. In addition, the Short Form-36 (SF-36) life quality scoring was used to evaluate the patients' quality of life in the pre- and postoperative first and sixth months. ${ }^{[14]}$

Postoperative morbidity included complications that occurred during the first postoperative month. Atrial fibrillation that necessitated medical treatment, postoperative pneumonia, prolonged air leak (longer than six days), and surgical wound infections were considered morbidities.

\section{Statistical analysis}

Statistical analysis was performed
using the IBM SPSS version 22.0 software


(IBM Corp., Armonk, NY, USA). Continuous variables were presented in mean \pm standard deviation (SD) or median (min-max), while categorical variables were presented in number and frequency. Demographics and clinical characteristics of the patients, such as age and hospital stay duration, were tested for normal distribution using the Kolmogorov-Smirnov test. The t-test was used to compare the group means for these variables, and the chi-square test was used to compare morbidity between the two groups. A $p$ value of $<0.05$ was considered statistically significant.

\section{RESULTS}

The study included 50 patients who received TENS in Group 1 and 50 patients who did not receive TENS in Group 2. Sixty patients underwent right-sided pulmonary resection, while 40 patients underwent left-sided pulmonary resection. Eighteen patients underwent thoracotomy due to possible malignancies.
After the frozen section reported benign lesions, further resection was not performed. Baseline demographic and clinical characteristics of the patients are shown in Table 1.

The mean length of hospital stay was $4.9 \pm 3.1$ days in Group 1 and 6.2 \pm 4.6 days in Group 2 ( $\mathrm{p}=0.008)$. There was no statistically significant difference between the groups in terms of early postoperative pain scores (Table 2).

The patients who received TENS had significantly better results according to Jensen et al.' $\mathrm{s}^{[13]}$ pain and life quality scale and also better pain perception in the first week of the postoperative period. This pain quality scores of Group 1 were lower than Group 2, indicating a statistical significance $(\mathrm{p}<0.05)$ (Table 3$)$. At the end of the first week, Group 1 had significantly lower pain scores compared to Group 2.

Table 1. Baseline characteristics of patients

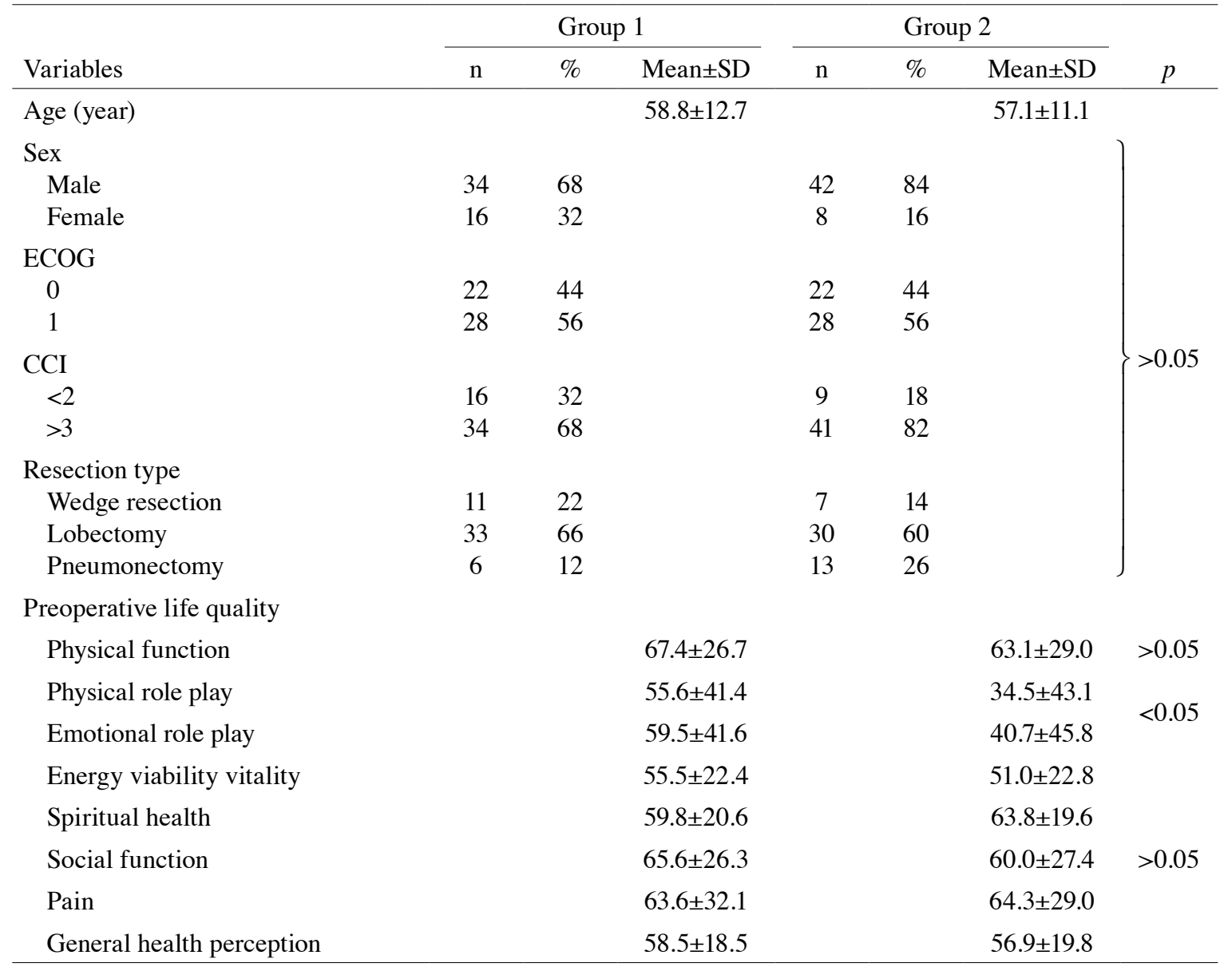

SD: Standard deviation; ECOG: Eastern Cooperative Oncology Group; CCI: Charlson Comorbidity Index. 
Table 2. Early-stage postoperative pain scores of patients

\begin{tabular}{|c|c|c|c|}
\hline \multirow[b]{2}{*}{ Variables } & Group 1 & Group 2 & \multirow[b]{2}{*}{$p$} \\
\hline & Mean \pm SD & Mean \pm SD & \\
\hline \multicolumn{4}{|l|}{ VAS scores } \\
\hline \multicolumn{4}{|c|}{ Postoperative Day 1} \\
\hline Rest & $4.3 \pm 1.9$ & $4.7 \pm 1.7$ & \multirow{7}{*}{$>0.05$} \\
\hline Cough & $6.3 \pm 2.1$ & $6.4 \pm 1.5$ & \\
\hline \multicolumn{4}{|c|}{ Postoperative Day 2} \\
\hline Rest & $3.4 \pm 1.8$ & $3.6 \pm 1.3$ & \\
\hline Cough & $5.1 \pm 1.8$ & $5.1 \pm 1.3$ & \\
\hline \multicolumn{3}{|c|}{ Postoperative Day 3} & \\
\hline Rest & $3.2 \pm 1.7$ & $3.2 \pm 1.3$ & \\
\hline Cough & $4.5 \pm 1.8$ & $4.3 \pm 1.5$ & \\
\hline
\end{tabular}

SD: Standard deviation; VAS: Visual Analog Scale.

There were nine complications (9\%): four patients (8\%) in Group 1 and five patients (10\%) in Group 2. In Group 1, one patient had a wound infection which was medically treated, two patients had pneumonia and one patient had atrial fibrillation which was also medically treated. In Group 2, one patient had atrial fibrillation, two patients had pneumonia, one patient had wound infection, and

Table 3. Evaluation of early-stage postoperative pain

\begin{tabular}{|c|c|c|c|}
\hline & Group 1 & Group 2 & \\
\hline Variables & Mean \pm SD & Mean \pm SD & $p$ \\
\hline Pain & $2.5 \pm 1.3$ & $6.1 \pm 2.4$ & \multirow{20}{*}{$<0.05$} \\
\hline Sting & $1.9 \pm 1.2$ & $6.1 \pm 2.7$ & \\
\hline Burning & $2.0 \pm 0.9$ & $5.5 \pm 2.9$ & \\
\hline Distress & $2.1 \pm 1.4$ & $6.5 \pm 2.4$ & \\
\hline Coldness & $1.8 \pm 0.7$ & $5.2 \pm 3.2$ & \\
\hline Sensitivity & $1.8 \pm 1.0$ & $5.6 \pm 2.9$ & \\
\hline Crushing feeling & $2.0 \pm 0.9$ & $5.4 \pm 3.1$ & \\
\hline Itching & $1.6 \pm 0.7$ & $5.5 \pm 3.0$ & \\
\hline Hitting feeling & $2.0 \pm 1.2$ & $6.1 \pm 2.8$ & \\
\hline Numbness & $1.8 \pm 1.1$ & $5.1 \pm 3.1$ & \\
\hline Electrification & $1.8 \pm 1.2$ & $5.1 \pm 3.2$ & \\
\hline Tingling & $1.8 \pm 0.7$ & $5.6 \pm 3.1$ & \\
\hline Cramp & $1.6 \pm 0.7$ & $5.1 \pm 3.2$ & \\
\hline Spread & $1.6 \pm 0.8$ & $5.4 \pm 3.0$ & \\
\hline Throbbing & $1.7 \pm 1.1$ & $5.1 \pm 3.2$ & \\
\hline Ache & $1.9 \pm 1.1$ & $5.5 \pm 2.9$ & \\
\hline Feeling of heaviness & $1.4 \pm 0.61$ & $5.4 \pm 3.1$ & \\
\hline Discontentment & $1.9 \pm 1.2$ & $5.6 \pm 2.9$ & \\
\hline Deep pain & $1.9 \pm 1.2$ & $5.6 \pm 2.6$ & \\
\hline Superficial pain & $1.9 \pm 1.2$ & $5.6 \pm 2.6$ & \\
\hline
\end{tabular}


Table 4. Evaluation of postoperative life quality

\begin{tabular}{|c|c|c|c|}
\hline \multirow[b]{2}{*}{ Variables } & Group 1 & Group 2 & \multirow[b]{2}{*}{$p$} \\
\hline & Mean \pm SD & Mean \pm SD & \\
\hline \multicolumn{4}{|c|}{ Life quality in postoperative month 1} \\
\hline Physical function & $83.0 \pm 19.0$ & $39.7 \pm 26.8$ & \multirow{8}{*}{$<0.05$} \\
\hline Physical role play difficulty & $81.2 \pm 28.6$ & $23.0 \pm 33.8$ & \\
\hline Emotional role play difficulty & $92.0 \pm 20.8$ & $26.1 \pm 37.6$ & \\
\hline Energy viability and vitality & $60.0 \pm 16.9$ & $42.7 \pm 15.0$ & \\
\hline Spiritual health & $59.0 \pm 17.1$ & $48.3 \pm 16.9$ & \\
\hline Social function & $74.1 \pm 16.4$ & $38.0 \pm 23.8$ & \\
\hline Ache & $75.6 \pm 15.9$ & $39.3 \pm 21.1$ & \\
\hline General perception of health & $62.6 \pm 19.4$ & $41.3 \pm 20.5$ & \\
\hline \multicolumn{4}{|c|}{ Life quality in postoperative month 6} \\
\hline Physical function & $91.8 \pm 18.0$ & $27.4 \pm 27.9$ & \multirow{8}{*}{$<0.05$} \\
\hline Physical role play difficulty & $94.5 \pm 20.4$ & $17.0 \pm 28.3$ & \\
\hline Emotional role play difficulty & $95.3 \pm 17.8$ & $28.66 \pm 40.4$ & \\
\hline Energy viability and vitality & $81.8 \pm 22.4$ & $48.90 \pm 16.2$ & \\
\hline Spiritual health & $79.3 \pm 21.7$ & $64.56 \pm 23.4$ & \\
\hline Social function & $78.1 \pm 19.4$ & $29.25 \pm 29.7$ & \\
\hline Ache & $88.5 \pm 17.4$ & $39.0 \pm 21.9$ & \\
\hline General perception of health & $80.7 \pm 26.6$ & $34.98 \pm 31.0$ & \\
\hline
\end{tabular}

SD: Standard deviation.

one patient had prolonged air leakage. Prolonged air leak spontaneously resolved on postoperative Day 10. The patients who received TENS had better life quality compared to those who did not in the first and sixth month postoperatively. Furthermore, these patients had also better pre- and postoperative life quality scores compared to the patients who did not receive TENS (Table 4).

\section{DISCUSSION}

Postoperative pain is commonly treated ineffectively. Although non-invasive thoracic surgery techniques have advanced recently, patients with highgrade lung cancer, central lung lesions, or concurrent pleural adhesions often require thoracotomy. In the postoperative period, pain can lead to complications such as pulmonary function disorders, secretion retention, atelectasis, and hypoxia. Although several studies have shown that TENS reduces early-stage postoperative pain, its exact mechanism of action remains speculative. Long-term TENS treatment prevents pain perception by increasing cerebral cortex activity, endorphin release, and causing spinal nerve blockade. ${ }^{[15-17]}$ One study reported that TENS reduced pain during hospitalization, but did not have an effect in the long-term. Erdogan et al. ${ }^{[18]}$ reported that TENS reduced early-stage postoperative pain and analgesic usage. Sezen et al. ${ }^{[10]}$ reported that TENS reduced pain, while it did not affect the complication rates, patient vitals, or hospitalization duration. In another study, Freynet and Falcoz ${ }^{[19]}$ reported that TENS decreased hospitalization duration and reduced pain levels significantly, when combined with analgesics; however, TENS alone was not sufficient for pain management. Fiorelli et al. ${ }^{[20]}$ also reported that TENS decreased cytokine release after posterior thoracotomy and that patients who received TENS had a better pulmonary capacity and required fewer narcotics. Sbruzzi et al. ${ }^{[9]}$ found that TENS led to significantly less pain after posterolateral thoracotomy. Similarly, Stubbing and Jellicoe ${ }^{[21]}$ showed that TENS did not provide any significant benefit in patients who received analgesic treatment. In our study, we used the Jensen et al. ${ }^{[13]}$ pain scale to evaluate pain 
levels and revealed that while TENS was ineffective for early-stage postoperative pain, it effectively reduced patients' pain levels in the first and sixth postoperative months. Although pain is presumptively associated with postoperative complications in TENS studies, few studies have demonstrated a significant relationship between TENS usage and complication rates. Stubbing and Jellicoe ${ }^{[21]}$ reported less nausea and vomiting in patients who received TENS. On the contrary, Sezen et al. ${ }^{[10]}$ and Fiorelli et al. ${ }^{[20]}$ did not report any significant association between TENS usage and postoperative complications. Of note, pulmonary rehabilitation in the early postoperative period is assumed to be the most important factor in the absence of complications.

In their study, Esteban González et al. ${ }^{[22]}$ reported that the physical functions of thoracotomy patients increased by early-stage TENS treatment. Freynet and Falcoz ${ }^{[19]}$ found that TENS not only improved pulmonary function, but also increased the shoulder joint activity. In our previous study using video-assisted thoracoscopy, lowering early-stage postoperative pain significantly increased the quality of life. ${ }^{[23]}$ These findings indicate that inhibiting early-stage pain prevents chronic neuropathic pain, which is the most important factor in improving quality of life. In our study, we used Jensen et al.'s ${ }^{[13]}$ pain and life quality scale to evaluate patients in the first week postoperatively. The patients who received TENS had better life quality and lower pain scores compared to those who did not $(\mathrm{p}<0.05)$. Based on these results, we can speculate that reduction of pain due to TENS in the early postoperative period improves quality of life of patients in the long-term.

In our study, we placed the TENS electrodes parallel to the surgical field as described previously. ${ }^{[10,17,19,22]}$ Fiorelli et al. ${ }^{[20]}$ reported that TENS reduced painstimulating cytokine release originating from the surgical field's muscles, when its electrodes were placed parallel to the surgical field.

In our study, although there was no relationship between TENS and early-stage postoperative pain, chronic pain statistically significantly reduced in patients who received TENS treatment. Furthermore, the TENS group had a better quality of life than the control group in the first and sixth postoperative months. Finally, physical, spiritual, emotional, and social functions were significantly better in the TENS group during the first postoperative month.

Although the study has a prospective design, the sample size of the study is relatively small. In addition, the study cohort was heterogeneous and included patients of a wide age range. Besides, the VAS scores are subjective methods to evaluate pain.

In conclusion, transcutaneous electrical nerve stimulation is an effective method to manage chronic pain in the postoperative period. On the other hand, it does not effectively reduce early-stage postoperative pain or affect complication rates. Based on our study results, prevention of chronic postoperative pain by transcutaneous electrical nerve stimulation application improves long-term quality of life of patients.

\section{Declaration of conflicting interests}

The authors declared no conflicts of interest with respect to the authorship and/or publication of this article.

\section{Funding}

The authors received no financial support for the research and/or authorship of this article.

\section{REFERENCES}

1. Macrae WA. Chronic pain after surgery. Br J Anaesth 2001;87:88-98.

2. Rogers ML, Duffy JP. Surgical aspects of chronic postthoracotomy pain. Eur J Cardiothorac Surg 2000;18:711-6.

3. Wildgaard K, Ravn J, Kehlet H. Chronic post-thoracotomy pain: a critical review of pathogenic mechanisms and strategies for prevention. Eur J Cardiothorac Surg 2009;36:170-80.

4. Bayram AS, Ozcan M, Kaya FN, Gebitekin C. Rib approximation without intercostal nerve compression reduces post-thoracotomy pain: A prospective randomized study. Eur J Cardiothorac Surg 2011;39:570-4.

5. Wu N, Yan S, Wang X, Lv C, Wang J, Zheng Q, et al. A prospective, single-blind randomised study on the effect of intercostal nerve protection on early post-thoracotomy pain relief. Eur J Cardiothorac Surg 2010;37:840-5.

6. Sezen CB, Aker C, Gokce A, Kalafat CE, Akboga SA, Sayan $M$, et al. Is intercostal nerve protection necessary and safe technique for postthoracotomy pain? Curr Thorac Surg 2019;4:26-33

7. Visagan R, McCormack DJ, Shipolini AR, Jarral OA. Are intracostal sutures better than pericostal sutures for closing a thoracotomy? Interact Cardiovasc Thorac Surg 2012;14:807-15.

8. Sezen CB, Kocatürk Cİ. Videothoracoscopic lobectomy training in non-small cell lung cancer. Turk Gogus Kalp Damar Cerrahisi Derg 2019;27:199-205.

9. Sbruzzi G, Silveira SA, Silva DV, Coronel CC, Plentz RD. Transcutaneous electrical nerve stimulation after thoracic surgery: Systematic review and meta-analysis of 11 randomized trials. Rev Bras Cir Cardiovasc 2012;27:75-87.

10. Sezen CB, Akboga SA, Celik A, Kalafat CE, Tastepe AI. Transcutaneous electrical nerve stimulation effect on postoperative complications. Asian Cardiovasc Thorac Ann 2017;25:276-80. 
11. Charlson ME, Pompei P, Ales KL, MacKenzie CR. A new method of classifying prognostic comorbidity in longitudinal studies: Development and validation. J Chronic Dis 1987;40:373-83.

12. Delgado DA, Lambert BS, Boutris N, McCulloch PC, Robbins AB, Moreno MR, et al. Validation of digital visual analog scale pain scoring with a traditional paper-based visual analog scale in adults. J Am Acad Orthop Surg Glob Res Rev 2018;2:e088.

13. Jensen MP, Gammaitoni AR, Olaleye DO, Oleka N, Nalamachu SR, Galer BS. The pain quality assessment scale: Assessment of pain quality in carpal tunnel syndrome. J Pain 2006;7:823-32.

14. Brazier JE, Harper R, Jones NM, O'Cathain A, Thomas KJ, Usherwood T, et al. Validating the SF-36 health survey questionnaire: New outcome measure for primary care. BMJ 1992;305:160-4.

15. Robertson V, Ward A, Low J, Reed A. Electrotherapy explained: principles and practice. 4th ed. Oxford: Elsevier Health Sciences; 2000.

16. Meesen RL, Cuypers K, Rothwell JC, Swinnen SP, Levin $\mathrm{O}$. The effect of long-term TENS on persistent neuroplastic changes in the human cerebral cortex. Hum Brain Mapp 2011;32:872-82.

17. Erden S, Senol Celik S. The effect of transcutaneous electrical nerve stimulation on post-thoracotomy pain. Contemp Nurse 2015;51:163-70.
18. Erdogan M, Erdogan A, Erbil N, Karakaya HK, Demircan A. Prospective, randomized, placebo-controlled study of the effect of TENS on postthoracotomy pain and pulmonary function. World J Surg 2005;29:1563-70.

19. Freynet A, Falcoz PE. Is transcutaneous electrical nerve stimulation effective in relieving postoperative pain after thoracotomy? Interact Cardiovasc Thorac Surg 2010;10:283-8.

20. Fiorelli A, Morgillo F, Milione R, Pace MC, Passavanti MB, Laperuta P, et al. Control of post-thoracotomy pain by transcutaneous electrical nerve stimulation: Effect on serum cytokine levels, visual analogue scale, pulmonary function and medication. Eur J Cardiothorac Surg 2012;41:861-8.

21. Stubbing JF, Jellicoe JA. Transcutaneous electrical nerve stimulation after thoracotomy. Pain relief and peak expiratory flow rate--a trial of transcutaneous electrical nerve stimulation. Anaesthesia 1988;43:296-8.

22. Esteban González P, Novoa NM, Varela G. Transcutaneous electrical nerve stimulation reduces post-thoractomy ipsilateral shoulder pain. A prospective randomized study. Arch Bronconeumol 2015;51:621-6.

23. Cansever L, Sezen CB, Bedirhan MA. Evaluation of the effect of video-assisted thoracoscopic surgery on early postoperative pain and quality of life. Curr Thorac Surg 2019;4:114-9. 